\title{
THE FIRST RECORD OF A MANGROVE RED SNAPPER, LUTJANUS ARGENTIMACULATUS (ACTINOPTERYGII: PERCIFORMES: LUTJANIDAE), FROM THE AEGEAN SEA (GULF OF IZMIR, TURKEY)
}

\author{
Okan AKYOL* \\ Faculty of Fisheries, Ege University, Urla, Izmir, Turkey
}

\begin{abstract}
Akyol O. 2019. The first record of a mangrove red snapper, Lutjanus argentimaculatus (Actinopterygii: Perciformes: Lutjanidae), from the Aegean Sea (Gulf of Izmir, Turkey). Acta Ichthyol. Piscat. 49 (2): 209-211.
\end{abstract}

\begin{abstract}
A specimen of Lutjanus argentimaculatus (Forsskål, 1775) was caught on 4 October 2018 by a commercial gillnet fishery from shallow waters of the Gulf of Izmir, northern Aegean Sea, at a depth of $8 \mathrm{~m}$. The presently reported study constitutes the first record of the mangrove red snapper for the Aegean Sea but also the third record for the Mediterranean Sea.
\end{abstract}

Keywords: Lessepsian fish, northernmost record, distribution, Mediterranean Sea

\section{INTRODUCTION}

The family Lutjanidae (snappers) includes 112 species occurring in all tropical and subtropical seas (Froese and Pauly 2019), and only three of them-Lutjanus argentimaculatus (Forsskål, 1775), Lutjanus fulviflamma (Forsskål, 1775), and Lutjanus sebae (Cuvier, 1816) - originating from the Red Sea, were collected off Lebanon, Malta, and the Saronikos Gulf of Greece in the Mediterranean, respectively (Golani et al. 2006, Vella et al. 2015). Zenetos et al. (2016), however, believed that the latter two species (i.e., L. fulviflamma and L. sebae) might have been potentially introduced into the Mediterranean via aquarium trade or shipping. However, a large specimen of $L$. sebae $(11.2 \mathrm{~kg})$ has been recorded for the second time off NW Sicily from the Tyrrhenian Sea in December 2016 (Gerovasileiou et al. 2017).

The mangrove red snapper, Lutjanus argentimaculatus, is a benthic fish species preferring rocky substrates down to the depth of $80 \mathrm{~m}$, although, young fish occur in shallow waters and often enter estuaries (Golani et al. 2006). Adults are frequently found in schools around coral reefs. They feed predominantly on fishes and crustaceans, reaching $150 \mathrm{~cm}$ of total length (TL), but usually not exceeding $80 \mathrm{~cm}$. The maximum recorded weight was 8.7 $\mathrm{kg}$ (Froese and Pauly 2019). Lutjanus argentimaculatus is an important commercial species in the Indo-Pacific region, but can never be found in large numbers (Froese and Pauly 2019). In Pakistan, Singapore, Malaysia, Thailand, and the Philippines this snapper is commercially cultured (Russell et al. 2016).

Mangrove red snapper is distributed throughout the Indo-Pacific - east Africa (including Madagascar,
Mauritius, Reunion, and the central islands of the Federated States of Micronesia), north to the Red Sea and the Persian Gulf, east to Samoa and the Line Islands, north to the Ryukyu Islands, south to Australia. It has dispersed into the eastern Mediterranean via the Suez Canal but it is not well established there (Russell et al. 2016, Froese and Pauly 2019).

\section{MATERIAL AND METHODS}

On 4 October 2018, a specimen of Lutjanus argentimaculatus, measuring $305 \mathrm{~mm}$ TL (Fig. 1) was captured by a commercial gillnet of $72 \mathrm{~mm}$ mesh size from the shallow waters off Urla, Gulf of Izmir, northern Aegean Sea (coordinates: $38^{\circ} 22^{\prime} \mathrm{N}, 026^{\circ} 47^{\prime} \mathrm{E}$ ) at a depth of $8 \mathrm{~m}$ (Fig. 2). The specimen was fixed with $5 \%$ formaldehyde solution and deposited in the ichthyological collection of the Fisheries Faculty, Ege University, Izmir under the catalogue number ESFM-PIS/2018-07.

\section{RESULTS AND DISCUSSION}

Brief description of the specimen. Body moderately compressed and deep, several large pointed teeth, caudal fin nearly truncate, and a notch in the lower margin of the operculum. Colour: back and sides greenishbrown to reddish; belly silvery or white. Description and the absolute and relative (\%TL) values of the body measurements (Table 1), recorded in this new specimen of L. argentimaculatus are in accordance with Golani et al. (2006) and Russell et al. (2016).

In the Mediterranean Sea, L. argentimaculatus has been recorded for the first time from Lebanon by Mouneimné (1979), and four decades later (in 2014), the second specimen 


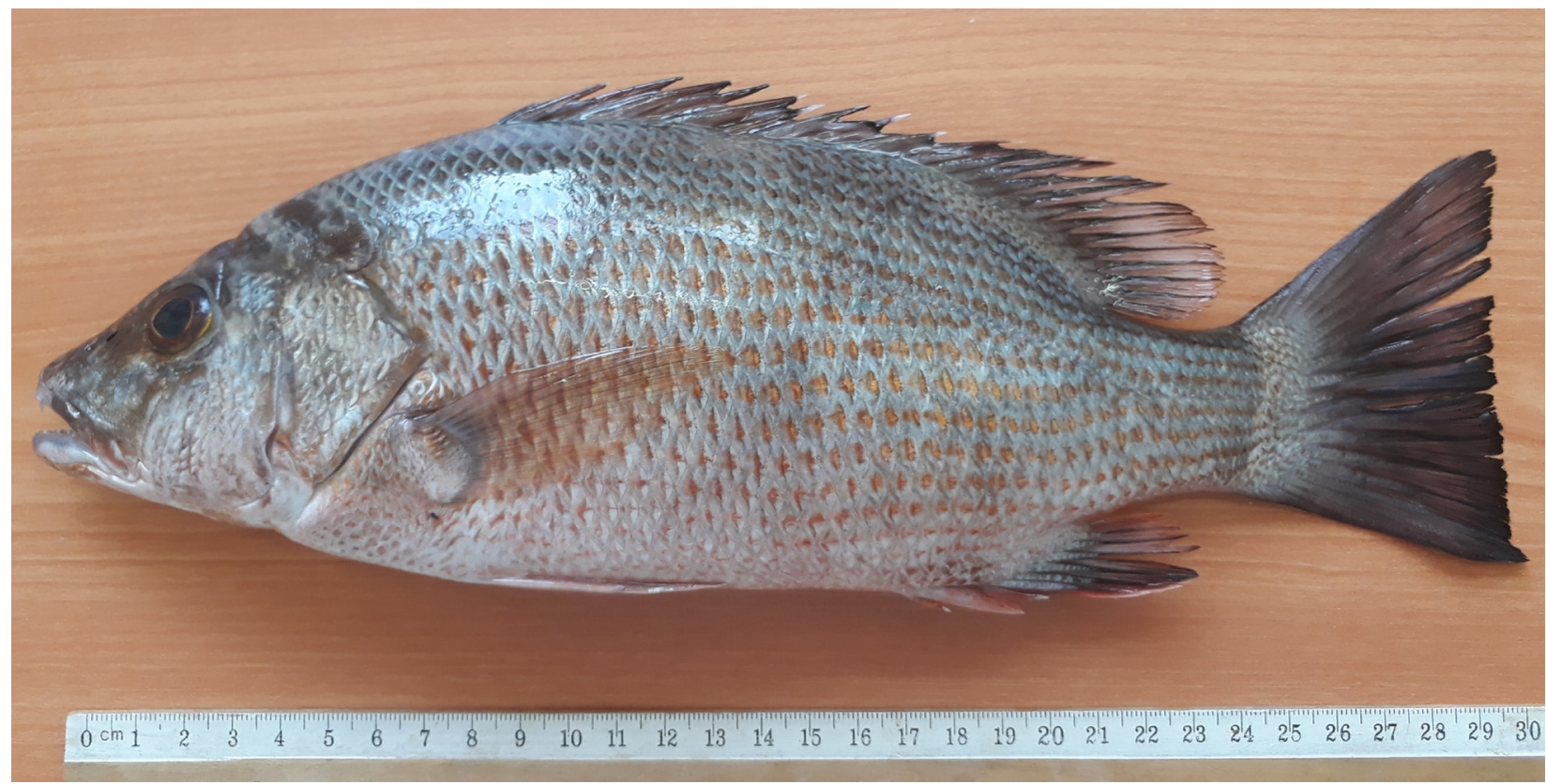

Fig. 1. Mangrove red snapper, Lutjanus argentimaculatus (ref. ESFM-PIS/2018-07), captured from the Gulf of Izmir, Aegean Sea

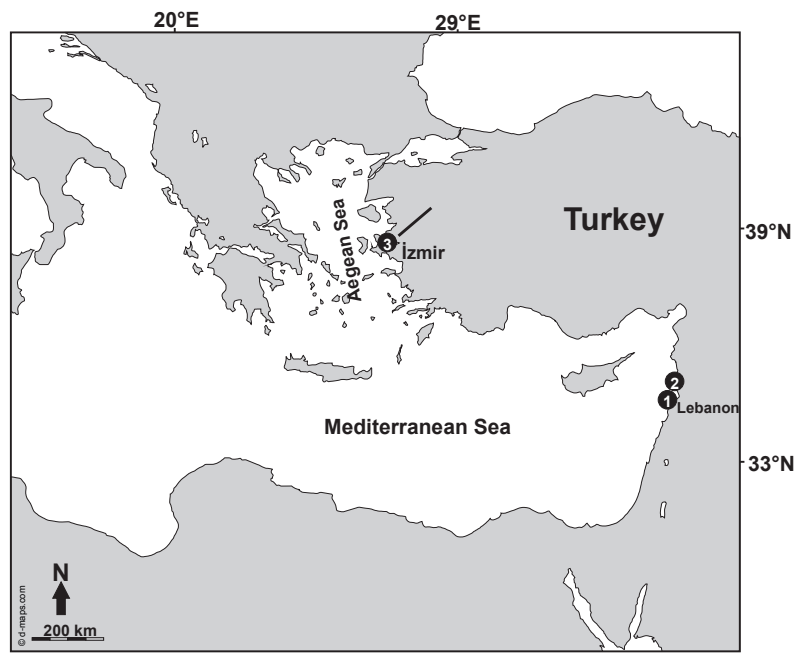

Fig. 2. Range extension of Lutjanus argentimaculatus in the coastal areas of the Mediterranean Sea (numbers and arrow indicate consecutive reports and the most recent record, respectively)

was collected in Tripoli, Lebanon at a depth of $45 \mathrm{~m}$ (Dailianis et al. 2016). Both records suggest that the fish range has not yet expanded beyond the borders of Lebanon. Thus, this ichthyological note presents not only the northernmost record of the L. argentimaculatus in a certain area of the Gulf of Izmir, northern Aegean Sea but it also constitutes the third record of this snapper in the Mediterranean Sea.

In conclusion, the occurrence of $L$. argentimaculatus is very rare due to only three specimens recorded in the last four decades in the Mediterranean Sea. This report is of particular significance as the confirmed finding of
Table 1

Morphometric measurements in $\mathrm{mm}$ and as percentage of total length (\%TL) and counts recorded in Lutjanus argentimaculatus, captured from the Gulf of Izmir, Aegean Sea

\begin{tabular}{|c|c|c|}
\hline Reference & \multicolumn{2}{|c|}{ ESFM-PIS/2018-07 } \\
\hline Measurements & {$[\mathrm{mm}]$} & {$[\% \mathrm{TL}]$} \\
\hline Total length & 305 & 100.0 \\
\hline Standard length & 260 & 85.2 \\
\hline Predorsal fin length & 95 & 31.1 \\
\hline Prepectoral fin length & 85 & 27.9 \\
\hline Preanal fin length & 177 & 58.0 \\
\hline Pectoral fin length & 58 & 19.0 \\
\hline Head length & 90 & 29.5 \\
\hline Eye diameter & 16 & 5.2 \\
\hline Preorbitary length & 28 & 9.2 \\
\hline Interorbital length & 16 & 5.2 \\
\hline & & \\
\hline Dorsal fin rays & \multicolumn{2}{|c|}{$X+14$} \\
\hline Anal fin rays & \multicolumn{2}{|c|}{$\mathrm{III}+8$} \\
\hline Pectoral fin rays & \multicolumn{2}{|c|}{16} \\
\hline Ventral fin rays & \multicolumn{2}{|c|}{$I+5$} \\
\hline Total body weight [g] & \multicolumn{2}{|c|}{473} \\
\hline
\end{tabular}

the mangrove red snapper in a certain area. Globally, the finding locality is the northernmost and considering that the Gulf of Izmir is too far from the first finding site (i.e., Lebanon) and the species is not known from more distant Turkish and Syrian coasts. Therefore, the shipping can be assumed potential pathway, and as a matter of fact that a large international harbour is available in the Gulf of Izmir. 


\section{ACKNOWLEDGEMENTS}

I would like to express my sincere thanks to Mr Ibrahim Temiztepe, the director of the Urla Fishery Cooperative, for bringing the fish to my attention.

\section{REFERENCES}

Dailianis T., Akyol O., Babali N., Bariche M., Crocetta F., Gerovasileiou V., Chanem R., Gökoğlu M., Hasiotis T., Izquierdo-Muñoz A., Julian D., Katsanevakis S., Lipez L., Mancini E., Mytilineou C., Ounifi Ben Amor K., Özgül A., Ragkousis M., Rubio-Portillo E., Servello G., Sini K., Stamouli C., Sterioti A., Teker S., Tiralongo F., Trkov D. 2016. New Mediterranean biodiversity records (July 2016). Mediterranean Marine Science 17 (2): 608-626. DOI: 10.12681/mms.1734

Froese R., Pauly D. (eds.) 2019. FishBase. [Version 02/2019] http://www.fishbase.org

Gerovasileiou V., Akel E.H.K., Akyol O., Alongi G., Azevedo F., Babali N., Bakiu R., Bariche M., Bennoui A., Castriota L., Chintiroglou C.C., Crocetta F., Deidun A., Galinou-Mitsoudi S., Giovos I., Gökoğlu M., Golemaj A., Hadjioannou L., Hartingerova J., Insacco G., Katsanevakis S., Kleitou P., Korun J., Lipej L., Malegue M., Michailidis N., Mouzai Tifoura A., Ovalis P., Petović S., Piraino S., Rizkalla
S.I., Rousou M., Savva I., Şen H., Spinelli A., Vougioukalou K.G., Xharahi E., Zava B., Zenetos A. 2017. New Mediterranean biodiversity records (July 2017). Mediterranean Marine Science 18 (2): 355-384. DOI: $10.12681 / \mathrm{mms} .13771$

Golani D., Öztürk B., Başusta N. 2006. Fishes of the eastern Mediterranean. Publication No. 24, Turkish Marine Research Foundation, Istanbul, Turkey.

Mouneimné N. 1979. Poissons nouveaux pour les côtes libanaises (Méditerranée orientale). Cybium 3 (6): 105-110.

Russell B., Carpenter K.E., Smith-Vaniz W.F., Lawrence A., Sparks J.S. 2016. Lutjanus argentimaculatus. The IUCN Red List of Threatened Species 2016: e.T61250A3101831. DOI: 10.2305/ IUCN.UK.2016-3.RLTS.T61250A3101831.en

Vella A., Vella N., Darmanin S.A. 2015. First record of Lutjanus fulviflamma (Osteichthyes: Lutjanidae) in the Mediterranean Sea. Journal of the Black Sea/ Mediterranean Environment 21 (3): 307-315.

Zenetos A., Apostolopoulos G., Crocetta F. 2016. Aquaria kept marine fish species possibly released in the Mediterranean Sea: First confirmation of intentional release in the wild. Acta Ichthyologica et Piscatoria 46 (3): 255-262. DOI: 10.3750/AIP2016.46.3.10

Received: 11 October 2018 Accepted: 30 November 2018 Published electronically: 15 June 2019 